\title{
China and New Regionalism in Africa - Conflict or Coherence?
}

\section{Introduction}

What is Africa's best hope for advancing its development initiatives? Should each state seek to compete independently on the world stage? Should they seek to forge relationships with external partners and the power players in the world economy on a one-to-one basis? Or should they work together in conjunction with the economic giants of the globalised economy? Of these three possible approaches this article seeks to investigate the third. Can the African states use a regional approach to economic development whilst still engaging and benefitting from external benefactors? Or will the traditional and developing powerhouses in the world economy simply use Africa's efforts at regional integration as a way to garner favour and preferential access to African markets and resources?

In the post colonial and post independence period, many African states sought to work with the former colonialists overlords in an attempt to develop their economies through a regional approach. Many of these attempts created little real benefit to the African peoples themselves. In the wake of these failed attempts at development via the perceived benefits of regional integration, new movements developed. A new approach to regionalism has appeared in the last three decades, whose hallmarks are quite different to the old approaches to regionalism. It is the intent of this article to make an empirical investigation into the progress of these new approaches to regional integration or 'the new regionalism' as it is often dubbed. I also wish to add a further element to this investigation. The 'old regionalism' traditionally featured African states seeking trade policy rationalisation/integration/development under the tutelage and patronage of the western states. However, one of key characteristics of the 'new regionalism' is that new partnerships between developing economies and 
the African states are emerging. These partnerships have the ability to either greatly help the African states in the path to development through regional integration, or they may hinder and derail these attempts.

To this end I wish to investigate the greatest 'developing' economy in the world and its impact on Africa's regionalisation projects. I am referring here to China. China has shown interest in Africa as a continent that has huge potential and as one that can provide great benefit to China's rapid economic growth and expansion. To this end it seems particularly relevant to investigate how China seeks to expand its ties and increase its presence in the area. As both Africa and China can be seen as 'developing', albeit both at very different levels, it should be particularly interesting to see how these two geographical and demographic juggernauts work together in the pursuit of their own developments.

In order to undertake an empirical investigation of China's impact on Africa's regionalisation projects in a coherent manner a specific analytical paradigm will be used. Regional trade areas, agreements and associations that fit within the 'new regionalism' framework in Africa will be this paradigm. An outline of the new regionalism will be offered in the first section, along with an explanation of how this paradigm is different to the previous attempts or 'old regionalism' projects in Africa.

In order to 'ground' the concept of the new regionalism in Africa, an explanation of the manifestations of new regionalism in Africa will be given. While there are a huge number of regional trade organisations and overlapping agreements in place in Africa ${ }^{1}$, only a limited number of regionalisation and economic integration organisations will be focused on. The focus will be on the African Union, The 
Southern African Development community and the Economic Community of West African States. This is due in part to word limit constraints, however, it is also due to my intention to focus on the regional integration organisations that are the most dominant and have the highest capability to make real progress in terms of advancing the benefits of regionalisation. In addition these organisations are very outward facing. They interact with the international community in a very real way. It is also an intention to focus on organisations that have links with the Chinese government, so the most effective empirical review of China's impact on new regionalism as a whole in Africa can be given.

After introducing the concept of new regionalism and outlining how it applies to Africa, the focus will shift to China. A review of China's intentions and recent actions on the African continent will be offered. Particular attention will be paid to China's support (or lack of support) for the African states' regional economic integration projects. Such as support for technical policy committees, funding for regionalisation organisations and investment and support for the development of 'regionalisation infrastructure' and all that this entails. China's official Africa policy will be given coverage and everything will be grounded by offering some raw economic data on the scale of China's trade and investment interaction with the African states.

The final section will attempt to bring the empirical data and analytical paradigms used together to reach a viable conclusion on whether China's action in Africa has impeded or supported the regional integration efforts currently underway. This will be done via two sub sections, one addressing the conflict between Chinese actions and new regionalism projects in Africa, and the other addressing any coherence. In an attempt to contextualise the conflict section via the real world experience of

\footnotetext{
${ }^{1}$ See diagram on page 30, 'Strategic plan of The Commission of the African Union, Volume 2:2004-2007 Strategic Framework of the Commission of the African Union', May 2004,
} 
regionalisation 'on the ground', an outline of some of the failed attempts and regionalisation in the past will be given. These failures will be juxtaposed against current Chinese action to see if China may be dooming African to repeat the mistakes of the past. Under the coherence section, coverage will be given to explicit examples of Chinese support for new regionalism initiatives, along more 'secondary' modes of support such as foreign direct investment (FDI) flows and resource extraction capability investment. The conclusions reached in the final section will then be recapped and discussed.

\section{New Regionalism}

The last two decades have seen a large influx of regional trade agreements (RTAs) into the globalised economic environment. As at December 2008 there are 421 RTAs which have been notified to the World Trade Organisation (WTO), 230 of which were in force. ${ }^{2}$ Just five years prior there were only 184 of these agreements in force. ${ }^{3}$ The ingrained and widespread nature of these agreements can be seen by the fact that almost every member of the WTO is a member of at least one RTA. Some WTO members are signatories to more than 20 of these agreements. ${ }^{4}$ Regional trade agreements can potentially benefit a wide range of states regardless of what state of 'development' their economies are in. Within the African context this may be particularly relevant, as regional trade organisation and integration efforts that seek to implement RTAs are becoming very widespread. This section will focus on outlining and explaining a specific paradigm of regionalism, namely the concept of

Commission of the African Union, Addis Ababa, Ethiopia.

2 'Regional Trade Agreements', (http://www.wto.org/english/tratop e/region e/region e.htm) World Trade Organisation.

${ }^{3} \mathrm{Pg} 1$, Burfisher, Mary E, Robinson, Sherman, Thierfelder, Karen, 'Regionalism: Old and New, Theory and Practice', (Paper prepared for The International Agricultural Trade Research Consortium). 
'The New Regionalism'. It will address the features of 'new regionalism', such as the kinds of projects, agreements and development initiatives that fall within this paradigm. In order to try and elucidate the complexities of these projects in a clear and concise way the goals and mission statements of these 'new regionalisms' will be referred to. This will be done by explaining what these projects seek to achieve for their regions' development.

The agreements, initiatives and projects that fall within the 'new regionalism' paradigm represent a fresh approach to an old idea. They are an attempt to use economic integration, trade facilitation and monetary policy rationalisation as a way to breathe life into struggling or developing economies. Here this 'fresh approach' to regionalism and economic integration will be addressed, by outlining and discussing the key features and manifestations of the new regionalism. As a way to further explain the 'newness' of this approach, a comparison will be offered between the old regionalism and the new regionalism, or in other words what makes the new regionalism new?. What are features of this 'new regionalism'? What would a region look like which has undergone or is working towards a more integrated economy? How would a more integrated approach to regional development manifest itself? Here an attempt to answer these questions will be undertaken by outlining the features of new regionalism. In particular what makes a region more or less regionalised and integrated? The concepts of shallow and deep integration will be referred to here, along with the specific projects and initiatives which give the concept of the new regionalism its pragmatic drive. Idealised implementation strategies will also be outlined and discussed.

\section{Old and New Regionalism}

\footnotetext{
${ }^{4} \mathrm{Pg}$ 1, Burfisher, Mary E, Robinson, Sherman, Thierfelder, Karen, 'Regionalism: Old and New, Theory and Practice', (Paper prepared for The International Agricultural Trade Research
} 
One of the clearest descriptions of the new regionalism is offered by Burfisher, Robinson and Thierfelder in a paper they presented to The International Agricultural Trade Research Consortium. Here they referred to how new regionalism exhibits deeper integration within region, as opposed to the historical attempts at regional integration. They also point out that the growing links and interdependence between developing and developed countries marks a demarcation between new and old regionalism. ${ }^{5}$ These two principles, namely growing interdependence between developing and developed countries and deeper integration within regions, will be the hallmarks of new regionalism for the purposes of this article. I intend to use Burfisher, Robinson and Theirfelder's classification of the new regionalism as a way to empirically investigate China's impact on new regionalism in Africa.

There are a number of features which speak to a deeper integration as referred to by Burfisher, Robinson and Thierfelder. In order to be clear about what is being referred to, what follows will be an outline of these features. The eight principles, as per Burfisher, Robinson and Thierfelder's statements, will feature in the most integrated regional economies. Thereby exhibiting an idealised version of the new regionalism, that is a region which is completely integrated and regionalised economically speaking. From this we can work back and see not only how African states' attempts at 'deploying' the new regionalism have advanced, but also the level of impact of China on this deployment.

By virtue of its name, the new regionalism suggests that there have been attempts at regionalism in the past. These attempts are ones which have failed to live up to the

\footnotetext{
Consortium).

${ }^{5} \mathrm{Pg}$ 2, Burfisher, Mary E, Robinson, Sherman, Thierfelder, Karen, 'Regionalism: Old and New, Theory and Practice', (Paper prepared for The International Agricultural Trade Research Consortium).
} 
expectations of their regions. Therefore they deserve to be revived and refocused from a new point of view. Here a comparison of the old regionalism to the new will be offered.

Burfisher, Sherman and Thierfelder offer some illuminating comments as to how old and new regionalism can be recognised and what the differences between the two descriptive paradigms are. One of the main ways they aim to explain the difference is by viewing regionalisms as integration at either a deeper or shallower level. They point out that the earliest efforts at regional integration can be witnessed during the first few decades after World War 2. During this phase of reconstruction and realignment of global economic currents attempts were made to integrate economies on a regional basis. Burfisher, Sherman and Theirfelder state that these efforts witnessed only shallow integration at best. They state that old regionalism and hence shallow integration focused mainly on simply reducing or eliminating barriers to trade. Whereas new regionalism and hence deeper integration focuses on a more complex set of principles such as harmonising national trade policies and encouraging internal mobility factors. ${ }^{6}$ These factors are characterised by such things as the movement of capital or labour, and they generally manifest as rules of origin policies, immigration policies and the development of intra regional trade infrastructure.

They point out that the Uruguay round of the negotiations on the General Agreement on Tariffs and Trade marked a turning point from old to new regionalism. The 1986 round of negotiations held in Uruguay was of fundamental importance to globalised trade practices for many regions, not least of which was due to the fact that this round led to the creation of the World Trade Organisation. 
Burfisher, Sherman and Theirfelder state that the negotiations that took place during this round exhibited agreements which showed a much deeper level of integration.

These agreements sought to progress beyond the traditional regionalisation agendas such as commodity trade and border protection policies, ${ }^{7}$ agendas which can be seen as hallmarks of the old regionalism. They also state that the regional trade agreements signed through the 1980s and 1990s have exhibited deeper levels of integration and they have also sought to link developing and developed countries. They state that these are the 'twin characteristics of the new regionalism.'

Burfisher, Sherman and Thierfelder state that 'new regionalism can be characterised as involving many of the elements found in the deepest levels of integration, and also via the achievements of a full economic and monetary union. ${ }^{8}$ They go on to describe features of an integrated economic region in terms of a hierarchy of integration elements. They state that there are a number of elements which could expect to be found in a highly integrated region; these eight elements are as follows (in order of increasing depth in terms of more integration). ${ }^{9}$

1. Facilitating financial and foreign direct investment flows.

2. Liberalising movement of labour within a regional trade area (agreement/association).

3. Harmonising domestic tax and subsidy policies.

4. Harmonising macro policies, including fiscal and monetary policies.

\footnotetext{
${ }^{6} \mathrm{Pg}$ 2, Burfisher, Mary E, Robinson, Sherman, Thierfelder, Karen, 'Regionalism: Old and New, Theory and Practice', (Paper prepared for The International Agricultural Trade Research Consortium).

${ }^{7} \mathrm{Pg}$ 2, Burfisher, Mary E, Robinson, Sherman, Thierfelder, Karen, 'Regionalism: Old and New, Theory and Practice', (Paper prepared for The International Agricultural Trade Research Consortium).

${ }^{8} \mathrm{Pg}$ 6, Burfisher, Mary E, Robinson, Sherman, Thierfelder, Karen, 'Regionalism: Old and New, Theory and Practice', (Paper prepared for The International Agricultural Trade Research Consortium).
} 
5. Establishing institutions to manage and facilitate integration.

6. Improvements of communication and transport infrastructure.

7. Harmonising legal regulation of product and factor markets.

8. Monetary union - establishment of a common currency. ${ }^{10}$

So if we view the above elements in order of regions exhibiting complete integration to limited/or the beginnings of integration, the list would look like this:

1. Monetary union - establishment of a common currency.

2. Harmonising legal regulation of product and factor markets.

3. Improvements of communication and transport infrastructure.

4. Establishing institutions to manage and facilitate integration.

5. Harmonising macro policies, including fiscal and monetary policies.

6. Harmonising domestic tax and subsidy policies.

7. Liberalising movement of labour within a regional trade area (agreement/association).

8. Facilitating financial and foreign direct investment flows.

The elements above are what we would expect deeply integrated regions to exhibit. Therefore successful or highly progressed new regionalisation projects could be characterised by the above characteristics. These elements are worth reflecting on as an investigation of China's impact on the progress of new regionalism in Africa is offered. In the next section where this investigation is attempted, the previous failures of regionalism in Africa (and whether China's current actions are in line with the root

\footnotetext{
${ }^{9} \mathrm{Pg}$ 6, Burfisher, Mary E, Robinson, Sherman, Thierfelder, Karen, 'Regionalism: Old and New, Theory and Practice', (Paper prepared for The International Agricultural Trade Research Consortium).

${ }^{10} \mathrm{Pg}$ 6, Burfisher, Mary E, Robinson, Sherman, Thierfelder, Karen, 'Regionalism: Old and New, Theory and Practice', (Paper prepared for The International Agricultural Trade Research Consortium).
} 
causes of these failures) will be juxtaposed against any examples of China facilitating the above elements. As these elements represent the idealised form of new regionalism, if China's actions are found to be either explicitly or indirectly supporting and promoting these elements, then a clearer conclusion will be able to be reached on whether China's activity in Africa is in conflict or coherence with the aims and strategies of new regionalism in Africa.

Burfisher, Sherman and Thierfelder also offer another set of characteristics of new regionalism which are generally accepted as clear characterisations of this paradigm by commentators within regionalism academia. These will be useful as another vehicle for elucidating the concept of new regionalism, and thereby hopefully providing a clearer analytical base for reviewing the impact of Chinese actions on the new incarnation of regionalism in Africa.

Burfisher, Sherman and Thierfelder see:

- technology and knowledge transfers, and technology diffusion, especially from developed countries to developing countries, that increase productivity

- dynamic comparative advantage and 'learning by doing' efficiency gains through increased demand from expanded trade

- increased foreign direct investment that carries with it advanced technologies and hence increases in productivity,

as further features and characterisations of the new regionalism. Again as with the previous section, these features will be juxtaposed against the 'conditions on the ground' relative to new regionalism in Africa and relative to China's support or indifference to these conditions. 
Manifestations of New Regionalism in Africa

The concept of new regionalism may seem like an idealised approach to regional integration, something which would struggle to make any progress in any real sense against the context of the complexities of African inter-state relations. However, Africa exhibits a vast array of interlocking, independent and interdependent manifestations of new regionalism. As referred to in the introduction, the vast scope and complexity of regionalisation organisations, initiatives, projects and RTAs means that for the purposes of this article, complete coverage of the entire African context cannot be given. An attempt has been made to focus on the regional trade organisations, and their practical manifestations via RTAs and initiatives that will be most relevant to an empirical review of China's impact on these mechanisms. To this end this article will be focussing on the African Union which was previously known as The Organisation of African Unity. Along with The Southern African Development Community and the Economic Community of West African States. As intimated in the introductory statements, these are the organisations which have the most relevance and opportunities to affect real change in terms of the regionalisation of Africa and the benefits that this entails. They also are the most relevant in terms of their outward facing nature. They have real and meaningful partnerships with many non-African states, most important of which is China for the purposes of this article. If we are to offer an interesting and relevant empirical investigation into China's impact on the advancement of the new regionalism in Africa, then surely we should focus on the groups which actually have interaction with China itself.

The African Union 
The African Union (AU), or previously The Organisation for African Union represents one of the longest and most sustained efforts at regional integration on a grand scale. The AU is a truly continental organisation whose membership consists of 49 African states. The AU is a regional integration organisation in the most holistic sense as it seeks, as the name suggests, not only regional integration but continental integration.

One of the key goals for the original Organisation of African Union was to bring together the wide variety of continental and sub-regional institutions and make them work together as one inter-related and integrated whole. ${ }^{11}$ The Sirte Declaration, issued when the AU was in its previous incarnation, called for 'The Establishment of an African Union, with a view, inter alia, to accelerating the process of integration in the continent to enable it to play its rightful role in the global economy while addressing multifaceted social, economic and political problems compounded as they are by certain negative aspects of globalisation. ${ }^{, 12}$

In order to address this call the Sirte Declaration set out the objectives of the AU, some of which were:

- to achieve greater unity and solidarity between African countries and the peoples of Africa

- to accelerate the political and socio-economic integration of the continent

- to establish the necessary conditions which enable the continent to play its rightful role in the global economy and in international negotiations

\footnotetext{
${ }^{11}$ Page 8, 'Strategic Plan of the Commission of the African Union', Volume 2:2004-2007, Strategic Framework of the Commission of the African Union, May 2004, Addis Ababa, Ethiopia.

${ }^{12}$ The African Union, 'About us/in a nutshell page' http://www.africaunion.org/root/au/AboutAu/au in a nutshell en.htm
} 
- to promote sustainable development at the economic, social and cultural levels as well as the integration of African economies

- to promote cooperation in all fields of human activity to raise living standards of African peoples

- to coordinate and harmonise the policies of existing and future regional economic communities for gradual attainment of the objectives of the union

- to work with relevant international partners in the eradication of preventable diseases and the promotion of good health.

The AU vision was updated and given more pragmatic drive in the 2004-2007 strategic plan document. The $\mathrm{AU}$ vision as per the updated document is it create a:

'United and integrated Africa; an Africa imbued with the ideals of justice and peace; an inter-dependent and virile Africa determined to map for itself an ambitious strategy; an Africa underpinned by political, economic, and social integration which would restore to Pan-Africanism its full meaning; an Africa able to make the best of its human and material resources, and keen to ensure the progress and prosperity of its citizens by taking advantage of the opportunities offered by a globalised world; an Africa engaged in promoting its value in a world rich in its disparities."13

In comparison with the statements made in the Sirte Declaration, the updated AU vision seems much more outwardly focused invoking terms like 'globalised world'. This may be particularly relevant given this article is interested in juxtaposing the goals of this organisation and others like it against the actions of the dominant 'developing economy', namely China. 
How does the AU propose to set about achieving the goals and promoting its vision for Africa? The Abuja Treaty signed in 1991, set the goal of the creation of an economic and monetary union for the members of the AU. This treaty stated that the harmonisation of regional economic communities was a key goal, as these communities were cited as the 'pillars of the $A U$ '. ${ }^{14}$ The $A U$ is also seeking to bring the myriad continental and sub-regional integration institutions together so that they can function with a more coherent strategy.

So how does the $\mathrm{AU}$ plan to meet the two main goals, namely the creation a regional economic community and a monetary union? The African Union's 2004-2007 Strategic Plan states in order to meet its goals a set of objectives with staggered deadlines will be worked towards. Its short term objectives for the years 2004-2007 will be to 'consolidate institutional pillars and build human networks. ${ }^{15}$ These statements refer to a wish to increase person-to-person and government-togovernment links between member states. This statement also speaks to a commitment to increase capacity of government organisations in member states which have been charged with working towards economic integration. The middle term strategic objectives for the years 2008-2015 are to 'ensure convergence of virile regional economic communities. ${ }^{, 16}$ This is referring to the associated mechanisms and initiatives which will allow functional regional economic communities to flourish and also allow these communities to group together in the continental context. Finally

\footnotetext{
${ }^{13}$ Page 6, 'Strategic Plan of the Commission of the African Union', Volume 2:2004-2007, Strategic Framework of the Commission of the African Union, May 2004, Addis Ababa, Ethiopia.

${ }^{14}$ Page 28, 'Strategic Plan of the Commission of the African Union', Volume 2:2004-2007, Strategic Framework of the Commission of the African Union, May 2004, Addis Ababa, Ethiopia.

${ }^{15}$ Page 12, 'Strategic Plan of the Commission of the African Union', Volume 2:2004-2007, Strategic Framework of the Commission of the African Union, May 2004, Addis Ababa, Ethiopia.
} 
the long term strategic goal which is to be achieved from 2015 onwards is to affect 'continental integration. ${ }^{17}$ This is the final phase and end goal of the AU.

In order to chart out how these goals will be achieved in the short to long term the AU set itself a number of strategic objectives for the period 2009-2012. The objectives for the AU's 'Development, Integration and Cooperation' programme are given via a three pronged approach. These goals are to be pursued through the strategic objectives themselves, the strategies for pursuing these goals and the organisations that are tasked with implementing the strategies. The development aspect of the programme outlines three objective areas, 'promote sustainable economic development', 'promote sustainable social and human development' and 'formulate frameworks for developing and sharing Africa's Statistics, and Research and Development capacities. ${ }^{18}$

The first objective area outlines strategies such as 'promote growth of intra-African trade and investments', 'accelerate infrastructure development with emphasis on interconnectivity, reliability and cost effectiveness' and 'promote agriculture development and food security. ${ }^{, 19}$ The second objective area outlines strategies such as 'develop and sustain human capabilities through increased access to health, education, nutrition, shelter' and 'promote policies and programmes on migration and combating human and drug trafficking. ${ }^{20}$, The third objective area outlines strategies such as 'promote and coordinate research and development initiatives amongst

\footnotetext{
${ }^{16}$ Page 12, 'Strategic Plan of the Commission of the African Union', Volume 2:2004-2007, Strategic Framework of the Commission of the African Union, May 2004, Addis Ababa, Ethiopia.

${ }_{17}$ Page 12, 'Strategic Plan of the Commission of the African Union', Volume 2:2004-2007, Strategic Framework of the Commission of the African Union, May 2004, Addis Ababa, Ethiopia.

${ }^{18}$ Page 24, 'Strategic Plan 2009-2012', African Union Commission, May 2009, Addis Ababa, Ethiopia.

${ }_{19}$ Page 24, 'Strategic Plan 2009-2012', African Union Commission, May 2009, Addis Ababa, Ethiopia.
} 
member states' and 'support the development of institutions for the promotion of technological invention, innovation and indigenous know how.'

The integration element has one strategic objective area, namely to 'strengthen continental integration.' This objective seeks to implement strategies to 'promote the free movement of people, goods, capital and services. ${ }^{21}$ The cooperation element also has only one strategic objective area which is to 'build and strengthen continental and global cooperation' via the 'promotion of growth of intra-African cooperation' and to 'establish and promote global strategic partnerships for Africa. ${ }^{22}$

The above is an outline of the AU's goals and strategies which are to be implemented to pursue their objectives. These goals and strategies will be part of the empirical basis whereby China's impact on this manifestation of new regionalism will be reviewed.

The Southern African Development Community

The Southern African Development Community (SADC) is a regional economic integration organisation operating in Southern Africa. One of the key aims of the SADC is to establish a regional free trade area amongst its member states.

The SADC has a membership of 15 states consisting of Angola, Botswana, Lesotho, Malawi, Mozambique, Swaziland, Tanzania, Zambia, Zimbabwe, Namibia, South Africa, Mauritius, Democratic Republic of Congo, Seychelles and until recently

\footnotetext{
${ }^{20}$ Page 25, 'Strategic Plan 2009-2012', African Union Commission, May 2009, Addis Ababa, Ethiopia.

${ }^{21}$ Page 27, 'Strategic Plan 2009-2012', African Union Commission, May 2009, Addis Ababa, Ethiopia.

${ }_{22}$ Page 28, 'Strategic Plan 2009-2012', African Union Commission, May 2009, Addis Ababa, Ethiopia.
} 
Madagascar. (Madagascar has recently been suspended due to the events of the March 2009 Malagasy Political Crisis.) The SADC vision is as follows; 'a common future, within a regional community that will ensure economic well being, improvement of the standards of living and quality of life, freedom and social justice; peace and security for the peoples of southern Africa. ${ }^{23}$

The SADC treaty outlines the general objectives of the organisation, which are as follows:

- to achieve development and economic growth, alleviate poverty, enhance the standard of the quality of life of the peoples of southern Africa and support the socially disadvantaged through regional integration

- to evolve common political values, systems and institutions

- $\quad$ to promote and defend peace and security

- to promote self-sustaining development on the basis of collective selfreliance, and the independence of member states

- to achieve complimentarity between national and regional strategies and programmes

- to promote and maximise productive employment and utilisation of natural resources and effective protection of the environment

- to strengthen and consolidate the long-standing historical, social and cultural affinities and links among the peoples of the region. ${ }^{24}$

The objectives above seem to follow the same 'development through regional integration' approach that the AU outlined. But how does the SADC seek to put these lofty goals into practice? In order to pursue these goals the SADC states that it will:

${ }^{23}$ SADC, 'SADC Profile' (http://www.sadc.int/) 
- harmonise political and socio-economic policies and plans of member states

- mobilise the peoples of the region and their institutions to take initiatives to develop economic, social and cultural ties across the region, and to participate fully in the implementation of the programmes and projects of SADC

- develop policies aimed at the progressive elimination of obstacles to free movement of capital and labour, goods and services, and of the peoples of the region generally within member states

- promote the development of human resources

- $\quad$ promote the development, transfer and mastery of technology

- improve economic management and performance through regional cooperation

- promote coordination and harmonisation of international relations of member states

- secure international understanding, cooperation and support, mobilise the inflow of public and private resources into the region

- develop such other activities as member states may decide in furtherance of the objectives of the SADC.

The SADC sees that the establishment of a free trade area amongst its member states has the ability to be a real impetus to reaching the goals it has outlined above. Background documentation regarding the purpose of the SADC states that 'The Free Trade Area is a step along the path towards deeper regional economic integration which is key to the strategy and objectives of SADC. ${ }^{, 25}$ In order to facilitate the

${ }^{24}$ SADC, 'SADC Profile' (http://www.sadc.int/)

${ }^{25}$ SADC, 'SADC Free Trade Area (FTA)' (http://www.sadc.int/fta) 
creation of the FTA in this context, the SADC states that its member states have already made considerable progress in areas such as:

- harmonising customs procedures and customs classifications

- increasing customs cooperation

- reducing costs by introducing a single, standardised document for customs clearance throughout the region

- establishing 'one stop' border posts which cut the time spent at the border in half

- making transhipment easier by enabling a single road to be used when transporting goods across several borders within the community.

The above outline of the SADC gives some background to its idealised function and objectives over the mid to long term. Again as with the AU example, the SADC in its capacity as an example of a manifestation of new regionalism in Africa will be used as an empirical basis for testing China's impact on the progress of these integration projects.

\section{Economic Community of West African States}

The final regionalisation and economic integration organisation I wish to give an outline of is the Economic Community of West African States (ECOWAS). This group encompasses a large geographic and demographic area. Many of its member states enjoy vast amounts of mineral, petro chemical and forestry resources - assets which China needs to drive its economic development. 
ECOWAS includes many of the states which have been given the 'least developed country' status; therefore they are a group that could potentially benefit greatly from the idealised benefits of regional economic integration. ECOWAS current membership consists of Benin, Burkina Faso, Cape Verde, Cote d'Ivoire, Gambia, Ghana, Guinea Bissau, Liberia, Mali, Nigeria, Senegal, Sierra Leone and Togo. ECOWAS has recently suspended two of its members, namely Guinea and Niger, both as a result of coup d'etat and/or associated political crisis.

The nature of the ECOWAS groups' initiatives and projects may seem slightly more basic and less grand in comparison with the AU and the SADC, however, this reflects the fact the ECOWAS states appear to be strictly in the 'capacity building phase'. Not just in terms of improving governance and rationalising trade policies in the region; rather ECOWAS seem to be working on the real fundamentals of developing their economies. The following outline of ECOWAS objectives, strategies and initiatives will highlight this fact. Even though ECOWAS may appear to be 'behind' or that they have a slightly more rudimentary approach towards economic integration in comparison with the other two groups, ECOWAS should still be considered a regional integration force. This group is also of particular relevance to the context of this article as China has considerable interests in this region, such as cotton in Benin, gold in Ghana and oil in Nigeria.

The Economic Community of West Africa States is a regional group of fifteen countries, founded in 1975. Its mission is to promote economic integration in 'all fields of economic activity, particularly industry, transport, telecommunications, agriculture, natural resources, commerce, monetary and financial questions, social and cultural matters. ${ }^{26}$ Its overall objective is 'to promote cooperation and integration

\footnotetext{
${ }^{26}$ ECOWAS Commission, 'ECOWAS in Brief' (http://www.comm.ecowas.int/sec/index.php?id=about a\&lang=en)
} 
with a view to establishing an economic and monetary union as a means of stimulating economic growth and development in West Africa. ${ }^{27}$ In order to meet this overall objective, ECOWAS outlined a number of objective areas and associated initiatives to pursue these objectives.

The 'trade and customs' objective area is one of the key areas in terms of how ECOWAS will seek to achieve its regional economic integration goals. Within the trade and customs context the establishment of a common market in West Africa is the key objective. The creation of a common market requires the creation of a free trade zone and the institution of a customs union. The implementation of these two mechanisms has been highlighted by ECOWAS as key steps on the road to the creation of the common market in West Africa. The ECOWAS states have also adopted a common approach to liberalising their trade and customs policies. This project includes initiatives such as the elimination of customs duties and taxes and the abolition of non-tariff barriers within Member States exchanges. ${ }^{28}$ The ECOWAS governments are also seeking to increase their capacity relative to the infrastructure of their financial institutions via measures such as establishing computerised data processing systems and developing software for the processing of external trade statistics. ${ }^{29}$ Further steps along the road to a common market in West Africa include the harmonisation of economic and fiscal policies among member states and the creation of a second monetary zone which will include The Gambia, Ghana, Guinea, Nigeria and Sierra Leone.

\footnotetext{
${ }^{27}$ ECOWAS Commission, 'ECOWAS programmes and activities - presentation', 2003, Abuja, Nigeria.

${ }^{28}$ ECOWAS Commission, 'ECOWAS programmes and activities - presentation', 2003, Abuja, Nigeria.

${ }^{29}$ ECOWAS Commission, 'ECOWAS programmes and activities - presentation', 2003, Abuja, Nigeria.
} 
The ECOWAS region is vast and includes a collection of landlocked states whose economic development will be heavily reliant on capable overland transport infrastructure. The ECOWAS member states have recognised this and have instituted a plan to develop their region's transport infrastructure in the hope that intra-region trade will benefit as a result. Some of the projects in this area include the construction of West African highway networks from Lagos, Nigeria in the east to Nouakchott, Mauritania in the west. This highway network would also run from Dakar, Senegal in the south to N'djamena, Chad in the north. In total the highway would cover around $11,000 \mathrm{~km}$ of interconnecting highways and roads. Other initiatives in the transport infrastructure area include the creation of a common insurance scheme, known as the 'brown card' scheme, along with an attempt to harmonise regulations relative to transport among member states. ${ }^{30}$

Along with transportation, consistent and well distributed energy supplies are key to economic development within the West African context. Again the ECOWAS member states have recognised this need, and in order to address this several energy-related projects have been implemented. The West African Gas Pipeline project is a key initiative in the quest to make better use of West Africa's natural resources, both for domestic energy requirements and also to enhance the ECOWAS states' energy export industry. The ECOWAS states have adopted a treaty which covers the implementation of the West Africa Gas Pipeline within four countries, Ghana, Togo, Benin and Nigeria. They also have a plan in place to facilitate the development of the means of energy production and interconnection of electricity grids in member states. This interconnection is to result in the creation of a West African energy system which will be known as the 'West African power pool. ${ }^{31}$

\footnotetext{
${ }^{30}$ ECOWAS Commission, 'ECOWAS programmes and activities - presentation', 2003, Abuja, Nigeria.

${ }^{31}$ ECOWAS Commission, 'ECOWAS programmes and activities - presentation', 2003, Abuja, Nigeria.
} 
Another key facet of improving infrastructure and capacity amongst ECOWAS states is the drive to update their current telecommunications systems. In order to address the deficiencies in current telecommunications capabilities ECOWAS has implemented a project which was dubbed INTELCOM 1. One of the initiatives under the telecommunications umbrella was the installation of a direct telephone, telex and fax connectivity between member states. Another was the establishment of a telecommunications centre in Lome, Togo. A sister project known as INTELCOM 2 sort to modernise the inter-state connectivity amongst ECOWAS nations. ${ }^{32}$

Finally ECOWAS have attempted to increase the capability of their agriculture sectors. As many of the states within western Africa rely primarily on agriculture, and in some states at subsistence levels, it will be of the utmost importance to develop these industries so they can be more productive and more reliable. To this end several projects were implemented to improve productivity in the agricultural sector. These included the establishment of seed production centres and the setting up of eight community cattle breeding centres in member states. ECOWAS states also sought to improve the production and inter community trade of livestock and animal products. ${ }^{33}$

The above section outlined the concept of new regionalism and provided some context on this paradigm via reference to regional economic integration organisations in Africa. These two issues, new regionalism and its manifestation in Africa will be the two concepts that are bought together and discussed in the final section. This will be

\footnotetext{
${ }^{32}$ ECOWAS Commission, 'ECOWAS programmes and activities - presentation', 2003, Abuja, Nigeria.

${ }^{33}$ ECOWAS Commission, 'ECOWAS programmes and activities - presentation', 2003, Abuja, Nigeria.
} 
done in order to see if China's actions in Africa are in coherence with the new regionalism paradigm or whether they are in conflict.

\section{China in Africa}

It is no secret that China has been pursuing an active partnership with many African states. China's rapidly growing economy will live and die on its ability to secure large amounts of resources and commodities. Africa represents a fertile ground for securing the building blocks China needs to maintain its current rapid growth.

How China goes about developing this partnership may serve to be a litmus test of sorts for a new way or form of the developed-developing state relationship. While Africa has the resources and potentially the manpower, it is lacking in many of the areas that are essential to develop these resources. Infrastructure at both public and corporate levels is well below par in many states. Many of the initiatives developed by African states to address these failings have fallen well short of their objectives. Can China, with its almost unlimited capital along with its experience and expertise in developing its own economy aide the African states in getting their regionalisation initiatives back up and running within this new dawn of regionalism? Or will China seek to do nothing more than pay lip service to the regional organisations, while only making just enough investment in infrastructure to get the minerals out of the hills and to the furnaces of mainland China?

Here I will address these questions by digging into the facets of China's involvement and growing relationship with Africa. Reference will be made to Beijing's official policy on Africa. How does it seek to engage with the African states and to what level does it aim to work at a regional level? Beijing's strategic short and long term goals will also be discussed with reference to its Africa policy. The nature of China's 
involvement 'on the ground' will be outlined. What and where it is investing and in what will be discussed. Its official economic assistance and aide projects will also be referred to. Finally some raw economic data will be offered so that the scope of China's involvement in Africa can be seen in a more real world sense.

This section will serve to highlight how and why China wishes to develop its relationship with the African states and organisations. The nature of China's involvement in Africa will then be tested against the 'best case scenario' for the deployment of the new regionalism on the continent, and also against previous failures of regionalisation projects. This will be done in order to see how China's actions in Africa may affect or may already be affecting the progress of new regionalism in Africa.

\section{China's Africa Policy}

The Chinese Government released its official policy on Africa in January 2006. The document entitled 'China's Africa Policy' covered China's plans for engagement with Africa. This document covered how China would support the development of the economies of African states and also how China aimed to access Africa's burgeoning markets and resource-rich primary sectors. Here coverage will be given to the Chinese government's statements regarding its official policy on Africa. Particular reference will be made to China's statements regarding the regionalisation organisations, namely the facets of this policy which speak to China's engagement in Africa and how these will either directly support or impede the project of new regionalism in Africa.

Within the initial section of the policy entitled 'Africa's position and role' specific reference is made to The African Union, and how China wishes to recognise this 
organisation as a key force increasing political security on the continent. ${ }^{34}$ This is a particularly bold and clear message of support for the African Union as one of the premier organisations that can secure a safe environment against which African states can pursue their development agendas. This speaks to China's reliance and possibly preference for dealing with this manifestation of new regionalism in Africa. It will be worth reflecting on these statements when we come to review how much China has supported or neglected new regionalism on the continent.

One of the key statements in the second section which is entitled 'China's relations with Africa' speaks to how China seeks to interact with Africa in an overall ideological sense. It goes as follows 'sincerity, equality and mutual benefit, solidarity and common development - these are the principles guiding China-Africa exchange and cooperation as the driving force to lasting China-Africa relations. ${ }^{35}$ Although these could appear to some as not much more than rhetoric drawn up by the diplomatic marketing staff, it could also be an important and deliberate piece of symbolism. By making this statement Chinese officials may be seeking to distance themselves from the kinds of arrangements other major powers have had with African states. The use of terms like 'mutual benefit' and 'common development' seem to speak to a more cooperative and less one-sided relationship in terms of interaction between Africa and external powers. China may be looking to represent itself as a power that seeks to work with the African states to develop economies and industry, rather than simply extracting resources and sending the profits back to Beijing. This could be important when we come to China's overall engagement approach with new regionalism in Africa.

\footnotetext{
${ }^{34}$ Part 1, 'China's Africa Policy', January 2006, Beijing, China (http://www.mfa.gov.cn/eng/zxxx/t230615.htm)

${ }^{35}$ Part 1, 'China's Africa Policy', January 2006, Beijing, China (http://www.mfa.gov.cn/eng/zxxx/t230615.htm)
} 
Similar statements are made in part three of China's Africa Policy where it states that one of China's general principles in Africa is 'sincerity, friendship and equality. China adheres to the Five Principles of Peaceful coexistence, respects African countries' independent choice on the road of development and supports African countries' efforts to grow stronger through unity. ${ }^{36}$ The references to 'independent choice on the road of development' are important here. It has been noted ${ }^{37}$ that one of the reasons for the failure of new regionalism in Africa is due in part to African states' unwillingness to cede the required amount of sovereignty to allow regional initiatives to advance. This will be covered further in the next section; however, this is an important thing to note at this stage.

Now we will move into the more explicit and detailed statements in terms of how China seeks to engage with the African states. The policy refers to China's intentions to facilitate the access of African goods to Chinese markets by granting duty free access to certain goods from the least developed countries. Further facilitation for joint ventures will be made via the China-Africa Joint Chamber of Commerce and Industry. It also states that 'when conditions are ripe, China is willing to negotiate Free Trade Agreements with African countries and African regional organisations., ${ }^{38}$ Here is a clear example of China's intentions relative to trade facilitation within the new regionalism paradigm.

Other pertinent statements within the policy include references to supporting infrastructure development in Africa. Within the 'infrastructure' section, the policy states that the Chinese government seeks to increase its cooperation with African

\footnotetext{
${ }^{36}$ Part 3, 'China's Africa Policy', January 2006, Beijing, China (http://www.mfa.gov.cn/eng/zxxx/t230615.htm)

${ }^{37}$ Pg558, Mistry, Percy S, 'Africa's record of regional co-operation and integration', October 2000, African Affairs.

${ }_{38}$ Part 4, 'China's Africa Policy', January 2006, Beijing, China (http://www.mfa.gov.cn/eng/zxxx/t230615.htm)
} 
states in their quest to improve transportation, communication, water conservancy, electricity and other infrastructures. Again this is another clear example of China seeking to support new regionalism in Africa, as one of the key vehicles to increase the progress of economic integration is to increase the capacity of infrastructure. ${ }^{39}$

Many 'development via regional economic integration' initiatives have been hamstrung by crippling debt repayment arrangements ${ }^{40}$ enforced on African states. It appears as though China has recognised this issue and is seeking to ease the burden of debt on the developing economies of African states. In reference to this matter China's Africa Policy states that 'China is ready to continue friendly consultation with some African countries with a view to seek solution to, or reduction of, the debts they owe to China. It will urge the international community, developed countries in particular, to take more substantial action on the issue of debt reduction and relief for African nations. ${ }^{41}$ This could be an important factor when we come to review how China's actions have impacted the progress of new regionalism in Africa. Some commentators have noted that harsh debt repayment agreements have forced some African states to be put their own domestic financial constraints ahead of regional economic concerns. ${ }^{42}$

The final section of China's Africa policy makes some of the most pertinent remarks in terms of the purpose of this article. This section is entitled 'China's relations with African Regional Organisations' and it refers to China's commitments to the current manifestations of new regionalism in Africa. The policy states that 'China appreciates

\footnotetext{
${ }^{39}$ Pg569, Mistry, Percy S, 'Africa's record of regional co-operation and integration', October 2000, African Affairs.

${ }^{40} \mathrm{Pg} 566$, Mistry, Percy S, 'Africa's record of regional co-operation and integration', October 2000, African Affairs.

${ }^{41}$ Part 4, 'China's Africa Policy', January 2006, Beijing, China (http://www.mfa.gov.cn/eng/zxxx/t230615.htm)

${ }^{42}$ Pg567, Mistry, Percy S, 'Africa's record of regional co-operation and integration', October 2000, African Affairs.
} 
the significant role of the $A U$ in safeguarding peace and stability in the region and promoting African solidarity and development. China values its friendly cooperation with the $A U$ in all fields, supports its positive role in regional and international affairs and stands ready to provide the AU assistance to the best of its capacity.' It also states that 'China appreciates and supports the positive role of Africa's sub-regional organisations in promoting political stability, economic development and integration in their own regions and stands to enhance its amicable cooperation with those organisations. ${ }^{43}$ This is a very clear example of China's intentions relative to its interaction with regionalisation organisations. It shows that China sees the African Union as not only the key regionalisation organisation, but it also shows that Beijing sees the $A U$ as a positive force in terms of how Africa interacts with the international community. Finally it speaks to a commitment to support the AU in all of its endeavours. These appear to be fairly clear statements regarding how China seeks to interact with this manifestation of new regionalism in Africa. However, as these are policy statements they should be tempered with a sprinkling of cynicism, and they need to be backed up by empirical evidence. This will be covered in the second part of this section.

\section{China's Activity in Africa}

This section will be a review of China's activity in Africa, both in terms of the level of trade between China and African states and also China's commitment to development projects on the continent.

China's recent record of trade with the African continent has seen some dramatic increases. The exports from African states to the Chinese market have increased at

\footnotetext{
${ }^{43}$ Part 6, 'China's Africa Policy', January 2006, Beijing, China (http://www.mfa.gov.cn/eng/zxxx/t230615.htm)
} 
around 50\% each year from 2000 to 2005 . As a comparison the growth rate of African exports to the US is two and a half times less and four times less to the European Union (EU). ${ }^{44}$ During this same period China's foreign direct investment (FDI) in Africa was around US\$1.3 billion. ${ }^{45}$ Although the majority of this FDI was for a time focused in states that have considerable oil and mineral deposits, this is beginning to change. As at 2004 Chinese FDI in Africa was around US\$900 million, however, total FDI from all countries in Africa at the same time was US\$15 billion. ${ }^{46}$ So as the reader will be able to see, Chinese investment in Africa was still relatively small in terms of total global investment.

China has had a lot history of providing economic and development aid to African states, stretching right back to the mid 1950s. Fifty years later China had provided $\$ 5.5$ billion in aid to the continent. ${ }^{47}$ The guiding principles of China's support for Africa's development were set during the early stages of this 'development partner' relationship. China stated that 'no conditions or demands for privileges' can be attached to the official development aid that is offered to Africa. ${ }^{48}$

China has supported the development of African economies by furnishing states with 'soft loans'. As at 2006 China had delivered US\$800 million worth of these concessional loans to the continent. These loans provided capital for over 50 different projects in 22 different states. ${ }^{49}$ In addition to providing soft loans China has sought to ease the burden of development in Africa by writing off large swathes of

\footnotetext{
${ }^{44} \mathrm{Pg} 1$, Broadman, Harry G, 'China and India go to Africa - New Deals in the developing world', March/April 2008, Foreign Affairs.

${ }^{45} \mathrm{Pg} 1$, Broadman, Harry G, 'China and India go to Africa - New Deals in the developing world', March/April 2008, Foreign Affairs.

${ }^{46} \mathrm{Pg} 13$, Ye Wang, Jian, 'What drives China's growing role in Africa', 2007, Working Paper, International Monetary Fund.

${ }^{47} \mathrm{Pg} 10, \mathrm{CHEKC}$ REFYe Wang, Jian, 'What drives China's growing role in Africa', 2007, Working Paper, International Monetary Fund.

${ }^{48}$ Pg11, Ye Wang, Jian, 'What drives China's growing role in Africa', 2007, Working Paper, International Monetary Fund.
} 
debt owed to it by various states. Beijing stated that it would write off US\$1.5 billion worth of loans owed to it by over 150 countries. This statement was delivered at the first China-Africa Cooperation forum in $2000 .^{50}$ Although China's Africa Policy was covered in the previous sub section it will be worth offering some more contexts in terms of actual commitment of funds to the continent. At the 2006 Beijing summit where the policy was delivered, the Chinese Government stated that it would double its current rate of economic and development assistance to African states by 2009 . Beijing would also provide a further US\$5 billion in concessional loans and credits to the African states. In addition to this China would cancel all interest-free debt that it was owned by 33 African states. Finally the Chinese Government sought to encourage further investment in Africa by establishing a US $\$ 5$ billion fund. ${ }^{51}$ In support of the wider economic development of African states China has been providing export credits, loans and investment guarantees for Chinese firms who are willing to invest in developing economies. These have been facilitated through the China Exim Bank. ${ }^{52}$

The Chinese aid programme offers support for a wide range of infrastructure and development-related projects. Technical assistance has been offered in the fields of agriculture and official development aid (ODA) has been given towards the delivery of humanitarian and infrastructure projects. ${ }^{53}$ However, the majority of the funding was provided for infrastructure projects, as at September 2006, 79\% of China's

\footnotetext{
${ }^{49} \mathrm{Pg} 3$, Broadman, Harry G, 'China and India go to Africa - New Deals in the developing world', March/April 2008, Foreign Affairs.

${ }^{50} \mathrm{Pg} 11$, Ye Wang, Jian, 'What drives China's growing role in Africa', 2007, Working Paper, International Monetary Fund.

${ }^{51} \mathrm{Pg} 3$, Broadman, Harry G, 'China and India go to Africa - New Deals in the developing world', March/April 2008, Foreign Affairs.

${ }^{52} \mathrm{Pg} 3$, Broadman, Harry G, 'China and India go to Africa - New Deals in the developing world', March/April 2008, Foreign Affairs.

${ }^{53}$ Pg11, Ye Wang, Jian, 'What drives China's growing role in Africa', 2007, Working Paper, International Monetary Fund.
} 
funding given via China Exim Bank was for infrastructure projects. ${ }^{54}$ Exim Bank being the main financial institution through which China's ODA is delivered.

Jian-Ye Wang of the World Bank points out that there has been a sizeable increase in China's ODA budget in recent times. He states that assuming Chinese aid comprises about half of the value of contracted projects, its ODA to sub Saharan African states could have been around US $\$ 1.5$ billion annually during 2004 and 2005. Whereas China's total aid into the continent from 1982-2002 was only US\$310 million annually. ${ }^{55}$ This speaks to the fact that China has rapidly increased the scope and nature of its activity in Africa during the last decade, in particular in the oil-rich sub Saharan states such as Angola and Nigeria. This may be interesting for the purposes of this article as both of these states are members of multiple regionalisation organisations, namely the Economic Community of West African States and the African Union. They are also states that could benefit from the infrastructure projects and associated integration initiatives which are part and parcel of the goals of these organisations. However, Wang reported that the last official statement from the Chinese Government regarding its development budget in Africa, delivered in 2002, stated that China had provided only US $\$ 1.8$ billion in economic support to Africa. This points to the fact that the official statements coming out of Beijing can sometimes contradict with the situation 'on the ground' in Africa, which is something worth considering.

The scope of these projects in terms of capital provided by China may seem impressive, however, the figures show that China's commitment to Africa has not

\footnotetext{
${ }^{54}$ Pg12, Ye Wang, Jian, 'What drives China's growing role in Africa', 2007, Working Paper, International Monetary Fund.

${ }^{55} \mathrm{Pg} 10, \mathrm{CHEKC}$ REFYe Wang, Jian, 'What drives China's growing role in Africa', 2007, Working Paper, International Monetary Fund.
} 
been that high in relative terms. As at 2005 the Chinese government had approved around US\$6.5 billion worth of funding for these projects. However, this was only $10 \%$ of China's Exim Bank's loans. ${ }^{56}$ Again there must be a proviso offered here, as Wang points out, that estimates made by World Bank staff for around this time are much higher, in fact they estimate that almost US $\$ 12.5$ billion had been delivered around this time.

The nature of the infrastructure investment is wide and varied; however, a large investment has been made in transportation networks. Over the last ten years Chinese companies have been very active in constructing and repairing road and rail networks. During this time over $6000 \mathrm{kms}$ of road has been built or earmarked for construction. More than $3000 \mathrm{kms}$ of railway tracks and associated infrastructure have also been constructed. ${ }^{57}$ Other important infrastructure developments have been facilitated via Chinese aid and investment. A steady power supply free from the threat of blackouts is of fundamental importance to any economy; this is particularly true to developing economies. Many African states have woefully inadequate power production and supply infrastructure. To support this facet of the development of African economies China committed itself to support the construction of eight large and medium sized power plants. ${ }^{58}$ More extensive detail of how this investment and ODA is being spent will be covered in the final section. This detail will be constrained to this section so a more direct comparison can be made between the goals and strategies of regionalisation organisations and the actions of China on the continent.

\footnotetext{
${ }^{56}$ Pg12, Ye Wang, Jian, 'What drives China's growing role in Africa', 2007, Working Paper, International Monetary Fund.

${ }^{57}$ Pg12, Ye Wang, Jian, 'What drives China's growing role in Africa', 2007, Working Paper, International Monetary Fund.

${ }^{58}$ Pg12, Ye Wang, Jian, 'What drives China's growing role in Africa', 2007, Working Paper, International Monetary Fund.
} 
The intent of the preceding section was to give the reader a brief outline of the scope and nature of China's interaction with the African states. There was an intentional focus placed on China's recent commitments to Africa in terms of FDI and ODA, however, some historical context was also provided. There was also an intentional focus placed on China's commitment to the manifestation of new regionalism in Africa, namely the regionalisation organisations such as the Africa Union. The remarks made in China's Africa policy coupled with references made to 'the conditions on the ground', namely the scope of China's FDI and ODA should hopefully clearly elucidate Beijing's commitment to the continent. Hopefully this will in turn serve as a good empirical grounding for a review of China's support or indifference towards the progress of new regionalism in Africa.

\section{Conflict or Coherence}

\section{Conflict?}

How have previous attempts at regionalisation in Africa faired? Have they managed to set themselves obtainable goals and make real progress in obtaining the benefits of regionalisation? This section will make reference to Percy Mistry's rather damning critique of Africa's record of regional cooperation and integration. This article outlines how and why regionalisation has failed in the past and some of the major factors that have impeded its progress. This critique will be used as a basis for a comparison with current Chinese actions, to see if they (China) have been putting the same roadblocks in the path of regionalisation as Mistry refers to. Due to the fact that Mistry is offering a historical critique of regionalism, the majority of his references 
relate to old regionalism, however, both old and new regionalism will be affected by the same negative factors relative to the advancement of regional economic integration.

Mistry's remarks may be particularly illuminating in reference to this question of how successful regionalism in Africa has been. He states that 'from an objective, impartial perspective, Africa's commitment to integration appears to have been visceral rather than rational, more rhetorical than real. African integration ideals have been based on lofty transcontinental ambitions, evocative political slogans, a plethora of treaties and regional institutions, high-minded principles and protectionist proclivities. ${ }^{59}$, Is this a fair approximation of Africa's record of regionalisation?

This section will cover the main stumbling blocks African states have run into in their quest for regional economic integration. This will be offered as a vehicle for assessing the impact of China's actions on the progress of current regionalisation projects in Africa. A historical account of the reasons why regionalisation projects have failed in Africa will be juxtaposed against China's current interaction with the states and their attempts at the 'new regionalisation'. This will be done as an attempt to see if China's current actions will doom the regionalisation in Africa to run into the same hurdles it met in the past. That is, are the actions of the Chinese state similar to other states which have impeded the progress of regionalisation in Africa?The answer to this question will hopefully create a clearer picture as to how much the actions of China are in conflict with the goals and strategies of new regionalism in Africa.

${ }^{59} \mathrm{Pg} 554$, Mistry, Percy S, 'Africa's record of regional co-operation and integration', African Affairs; Oct 2000; 99. 
Two conflicting pre-dispositions have influenced efforts at regional integration, namely:

- adherence to colonial borders drawn in European capitals

- emphasis from independence onwards, the importance of economic integration across Africa's sub regions and the continent as a whole. ${ }^{60}$

Both of these points from Mistry speak to the idea that the geographic make up and the large degree of importance placed on economic integration across the sub regions have led to a flawed implementation of regionalisation. Regionalisation projects are trying to work against fundamentally flawed geography, over inflated targets and over optimistic goals in relation to wholesale integration. Mistry points out that Africa is trying 'to remain politically separate while being convinced they need to achieve economic fusion at arms length, ${ }^{, 61}$ he states this has 'confused means and ends.'

There has been much reference made to the importance of infrastructure for developing economies, and in particular among states who are looking to develop inter-state trade via regionalisation. To this end Mistry points out that, 'After forty years of independence (article written in 2000), Africa's physical infrastructure still reflects its colonial inheritance.' He states that, 'its transport and communications links remain geared to extracting and exporting tropical beverages and minerals, they are not yet designed to foster inter Africa growth and trade. ${ }^{62}$ So the African states have still not made enough progress in terms of the infrastructure capability required to implement any real increases in inter-state trade. Without major upgrades to

\footnotetext{
${ }^{60} \mathrm{Pg} 553$, Mistry, Percy S, 'Africa's record of regional co-operation and integration', African Affairs; Oct 2000; 99.

${ }^{61} \mathrm{Pg} 553$, Mistry, Percy S, 'Africa's record of regional co-operation and integration', African Affairs; Oct 2000; 99.

${ }^{62} \mathrm{Pg} 554$, Mistry, Percy S, 'Africa's record of regional co-operation and integration', African Affairs; Oct 2000; 99.
} 
roads, rail and telecommunications, the sometimes lofty ideals of economic regionalisation will not have the means to advance.

Mistry paints a very bleak picture when referring to the progress of regionalisation projects in Africa. He states that 'it [regional integration] has not yet yielded results by way of enhanced efficiency, or in terms of successful industrialisation, market enlargement, modernisation, sustained development and growth, or competitiveness. ${ }^{63}$ In terms of the evolution of regionalism in Africa he claims that 'some of the first attempts at regional economic integration in Africa were characterised by agreements which advocated industrialisation through high levels of protection and development of closed markets in state run economies which were financed heavily by external official development aid. ${ }^{64} \mathrm{He}$ remarks that this approach resulted in little progress towards to goals of regionalisation or towards the objectives of the regional agreements as protectionism is liable to become firmly entrenched in Africa rather than it being seen as just one stage on the road to development. Mistry points out that protectionism in Africa becomes the end rather than the means of development. Mistry states that trying to use protectionism as a way to develop economies is destined to fail for the above reasons.

There are also some very pertinent historical examples of failures within specific regional trade organisations and agreements. The Economic Community of Central African States was setup to advance the goal of regional economic integration in an attempt to raise the living standard of its member's states citizens. One of the mechanisms for achieving this goal was to secure the free movement of goods, services and peoples across the central African states. This was to be achieved by

\footnotetext{
${ }^{63} \mathrm{Pg} 556$, Mistry, Percy S, 'Africa's record of regional co-operation and integration', African Affairs; Oct 2000; 99.

${ }^{64} \mathrm{Pg} 557$, Mistry, Percy S, 'Africa's record of regional co-operation and integration', African Affairs; Oct 2000; 99.
} 
the creation of a customs and monetary union, a common and external tariff and a central customs administration. However, these initiatives were railroaded by the confusing nature of the subsequent agreement, in which tariff preferences varied wildly, depending on what firm, product, country of origin or country of destination you were dealing with. ${ }^{65}$ Mistry points out that this created major distortions and obstacles to any real integration between the individual markets of member states. So within the context of the central African sub region, there were lofty ideals of how the ultimate 'integration product' would be delivered, but what resulted was not technically adequate. The detail of the subsequent arrangement managed to actually create more of the problems it originally sought to remedy.

As ECOWAS is one of the regionalisation organisation I referred to when outlining how new regionalism manifests in Africa, it would be relevant to see what stumbling blocks this group has run into along the road to its regionalisation goals. ECOWAS set itself similar goals regarding the creation of a customs union and a common market. However, Mistry points out that intra-regional trade was running at around $7 \%$ of total trade at the time of his article (2000) so, he states, the regional economic integration was far from reaching its goal. However, Mistry makes an important proviso, something which could be applied to many of the African sub regions. The progress of the creation of regional economic integration mechanisms has been hampered by large scale armed conflict among member states ${ }^{66}$ An example of this is the First and Second Liberian Civil War which was waged over 1989 and 1999 respectively. These conflicts implicated neighbouring states such as Burkina Faso and Cote d'Ivoire. If member states are in open conflict with each other, or even if they are implicated in a less explicit way, how can we expect them to be plotting

\footnotetext{
${ }^{65} \mathrm{Pg} 564$, Mistry, Percy S, 'Africa's record of regional co-operation and integration', African Affairs; Oct 2000; 99.

${ }^{66} \mathrm{Pg} 565$, Mistry, Percy S, 'Africa's record of regional co-operation and integration', African Affairs; Oct 2000; 99.
} 
military manoeuvres against each other on the one hand and then get together around the board room table and rationalising tariff rates on the other?

Mistry makes an interesting comment regarding the always controversial structural adjustment programmes (SAP). These programmes were implemented by the International Monetary Fund and the World Bank. They attached conditionalities on either getting new loans or restructuring loans under lower interest conditions for developing countries. He states that although some of the ECOWAS states have enjoyed some successes in terms of increased intra-regional trade, these successes are drying up as the harsh conditionalities of SAPs have forced many states to become more selfish and more insular. ${ }^{67}$ This speaks to an interesting point regarding the impact of external forces on regionalisation projects for struggling/developing economies. This may be worth remembering and reflecting on when we consider how China has managed its aid and finance offerings in Africa.

According to Mistry's work, some of the key obstacles to the progress of regional integration projects include:

- vested interests that have profited from development failure, these include Africa's leadership and state apparatus

- those officials and state organisations that are reluctant to accelerate a paradigm shift that weakens their power and reduces opportunities for satisfying the private agenda of pubic officials

- a failure of African governments to translate their commitments in regional treaties into real changes in their national policies

- an unwillingness shown by African governments to set aside national political interest in order to achieve long term regional economic goals

\footnotetext{
${ }^{67} \mathrm{Pg} 558$, Mistry, Percy S, 'Africa's record of regional co-operation and integration', African
} Affairs; Oct 2000; 99. 
- an unwillingness to cede the necessary amount of sovereignty to regional organisations

- no monitoring and enforcement mechanisms put in place to ensure adherence to agreed upon timetables relative to things like non-tariff barrier reductions. ${ }^{68}$

While these points relate more to the failures of the 'old' regionalism projects, Mistry also offers some advice on what needs to happen if the 'new' regionalisation efforts are to succeed. It will be illuminating to see how these 'requirements for regionalisation' fit against the actions of China to see if they are in conflict.

In terms of the general progression of regional integration in Africa, Mistry lists several prescribed approaches which may help, such as:

- African states need to make the right choices in terms of partnerships for regional integration if they are to succeed in meeting the goals of these regionalisation projects. He cites the Southern African Development Community (SADC) as a an example of this

- $\quad$ there needs to be a greater level of convergence among integrating economies relative to key macroeconomic and development indicators, such as interest rates, monetary policy and on general fiscal structure and policies

- integration efforts need to be backed up by formal agreements or arrangements with other established trading blocs. Mistry offers the EU as an example and states that this kind of relationship would bolster their credibility and durability. ${ }^{69}$

\footnotetext{
${ }^{68} \mathrm{Pg} 558$, Mistry, Percy S, 'Africa's record of regional co-operation and integration', African Affairs; Oct 2000; 99.

${ }^{69} \mathrm{Pg} 560$, Mistry, Percy S, 'Africa's record of regional co-operation and integration', African Affairs; Oct 2000; 99.
} 
The above section was designed to serve as a review of negative impacts on regionalisation projects in Africa which fall within the 'new regionalism' paradigm. For the purposes of reviewing China's impact on new regionalism, the negative impacts discussed above will be juxtaposed against any Chinese actions which may replicate these issues. Could China's recent interactions and relationships with the African states possibly cause these negative factors to reappear within the new regionalism paradigm? Or has China in fact actively avoided promulgating these impacts by pursuing a much more interdependent relationship with the African states relative to their regional integration efforts?

As was mentioned above and in previous sections, infrastructure development has been highlighted by many regionalisation organisations as a key part of the overall integration project. The importance of infrastructure development was further bolstered by Percy Mistry's comments, where he states that Africa's infrastructure projects have not met much real progress. Mistry states that the lack of progress has had a direct impact on regional integration projects, as the upgrades to things like communications and transport links required to increase inter African trade have not materialised. Has China's actions in Africa bolstered or hindered the development of infrastructure within the regionalisation context? It is my contention that China has supported the development of infrastructure on the continent, and that by supporting this important 'new regionalism' initiative China's actions are indeed in coherence with new regionalism in Africa in general. As part of one of the earlier sections, reference was made to China's planned commitment to Africa's development which was outlined in 'China's African Policy' and statements such as 'the Chinese government seeks to increase its cooperation with African states in their quest to improve transportation, communication, water conservancy, electricity and other 
infrastructures' ${ }^{70}$. These sorts of 'policy statements' coupled with empirical evidence such as the fact that the Chinese government via Chinese companies have built around $6000 \mathrm{kms}$ of roads, $3000 \mathrm{kms}$ of railroad tracks and constructed power plants, ${ }^{71}$ seems to be fairly solid evidence to support that contention that China is seeking to remedy this particular bug bear of new regionalism in Africa.

How the African states seek to open up their markets to external trade could be integral to the progress of regionalisation and economic integration. As outlined above, Mistry comments that previous attempts at regionalisation in Africa where characterised by protected closed markets. Closed markets will not foster the increase in inter-state trade within regions, nor will they help the development of trade and the African economies in a general sense. If we review China's actions relative to this particular stumbling block to regionalisation, has Beijing promoted or discouraged the introduction of a closed market policy within the developing African economies? Based on the statements in China's Africa Policy it appears as though Beijing is discouraging the spread of closed markets within these developing economies. This policy states that China will facilitate the access of African goods into Chinese markets via the adoption of duty free access for certain goods from certain African states. China seeks to take this arrangement to the ultimate logical conclusion, namely to eventually create a network of free trade agreements with African states and African regional organisations. ${ }^{72}$ By fostering free trade and discouraging the spread of closed market practices, China's appears to be supporting the African regional organisations in their efforts to avoid the pitfalls of this particular approach to new regionalism.

\footnotetext{
${ }^{70}$ Pg569, Mistry, Percy S, 'Africa's record of regional co-operation and integration', October 2000, African Affairs.

${ }^{71}$ Pg12, Ye Wang, Jian, 'What drives China's growing role in Africa', 2007, Working Paper, International Monetary Fund.

${ }^{72}$ Part 4, 'China's Africa Policy', January, 2006, Beijing, China (http://www.mfa.gov.cn/eng/zxxx/t230615.htm)
} 
The political and geo-strategic context within the African 'regions' will obviously have a huge impact on the progress of new regionalism on the continent. This was alluded to in the above section, with specific reference to the first and second Liberian Civil War and the impact these events had on the progress of the ECOWAS integration programme. Has China been working to support peace keeping initiatives in Africa as a way to avoid the negative impact conflict can have on regional integration projects? The statements made in 'China's Africa Policy' indicates a strong will to work towards a more stable continent, particularly through China's cooperation with the AU. This policy refers to China's appreciation of what the $A U$ is doing for regional stability. At the most recent meeting of the Forum on China-Africa Cooperation, the Chinese side reaffirmed this appreciation and restated its commitment to supporting the $A U$ in these endeavours. The action planned which resulted from this meeting featured several clear statements relative to Chinese support for peace keeping via the AU. For example, Section 2.6.2 states that 'The Chinese Government appreciates the concept and practice of 'Solving African Problems by Africans. It will continue to support the efforts of the $\mathrm{AU}$, other regional organisations and countries concerned to solve regional conflicts, and will intensify cooperation with African countries in peacekeeping theory research, peacekeeping exchanges and in supporting the building of peacekeeping capacity in Africa. ${ }^{73}$ This commitment from the Chinese government speaks to a clear intention to support and develop peace keeping capability in Africa. We could conclude from this that China is supporting the African states in their efforts to not let regional conflict railroad the progress of the new regionalism.

As would be expected, many developing economies within Africa have had to rely on external funding in order to secure the capital they need to pay for vital domestic

\footnotetext{
${ }^{73}$ Pg15, African Union Commission, 'Forum on China-Africa Cooperation, Sharm el Shiekh Action Plan (2010-2012), 12 November, 2009, Addis Ababa, Ethiopia.
} 
services and projects. This funding has often come in the form of loans provided by financial institutions based mainly in western states. As referred to in the above section, Percy Mistry pointed out that the repayment plans and resulting structural adjustment programmes which appear due to certain states' inabilities to repay loans, have caused many problems for regional integration initiatives. The conditionalities attached to these repayment plans have forced many African states to become more insular and inwardly focused, which in tern has a negative impact on regional economic concerns. ${ }^{74}$ Have China's activities and commitments to the African states and regional organisations had a negative or positive impact on the constricting influence of state debt on the continent? As part of the Chinese government's commitment to support the developing of African economies they have outlined a raft of debt reduction and cancellation arrangements. For example, at the 2006 Beijing summit the Chinese government indicated that it would cancel all interest-free debt that was owed to it by 33 African states. This was in addition to the cancellation of US $\$ 1.5$ billion worth of debt which was cancelled in 2000 . So in terms of easing the burden of debt relative to the progress of regional economic integration, China appears to be supporting this part of the overall successful facilitation of new regionalism in Africa.

Based on the above it appears as though the Chinese Government's actions relative to African regionalisation organisations have been mostly positive. Their actions do not seem to be leading into or producing the same road blocks to regionalisation as outlined in the work of Percy Mistry. China has facilitated and supported the development of badly needed infrastructure in African states. They have promoted the expansion of African markets into new realms, thereby avoiding the potential pitfalls of closed markets. The Chinese military has supported peace keeping efforts

\footnotetext{
${ }^{74} \mathrm{Pg} 558$, Mistry, Percy S, 'Africa's record of regional co-operation and integration', African Affairs; Oct 2000; 99.
} 
within African regions, thereby providing local governments with a much more stable ground from which they can seek to advance economic integration initiatives. Finally, China's sympathetic stance on debt forgiveness will hopefully allow African states to focus more on regional economic concerns rather than the individual state level constraints that have resulted from the SAP conditionalities. Reviewing something as complex as one external states' impact on the progress of something as potentially abstract and ethereal as regionalisation is tricky. However, by focusing on specific stumbling blocks to regionalisation and how China has acted relative to these challenges I believe we can come to some meaningful conclusions. Namely, that China has sought to alleviate these challenges where possible and that they have tried to implement initiatives which can be seen to support Africa's attempts at regionalisation.

\section{Coherence?}

Based on the conclusions reached above, China has not actively impeded the progress of new regionalism in Africa by replicating the negative impacts which have plagued regional integration efforts in the past. However, how has China actively supported new regionalism in Africa? This section will review China's activity relative to projects such as infrastructure development, technical support for the rationalisation of trade policies and the facilitation of market access. These kinds of projects are the sorts which could be expected to have a real positive impact on the progress of new regionalism in Africa.

China reaffirmed its relationship with Africa when it announced a new set of commitments at the 2006 Forum on China-Africa cooperation. Many of these commitments speak directly to China's support for the mechanisms required to effectively implement new regionalism in Africa. The Chinese Government is 
supporting and facilitating investment in Africa through the establishment of a ChinaAfrica development fund. This fund is worth around US\$5 billion. The facilitation of more external investment is a key step on the road towards economic integration, as investment is the backbone of many facets of the integration effort. Investment will not only allow infrastructure projects to proceed, but it can also stimulate local industry via the creation of new production and processing facilities.

I would like to offer a few examples of this in practice, to hint at the share scale of Chinese investment in Africa, and how much this may facilitate the advancement of African industry in general. This is because increasing the efficiency and scope of industry in general is obviously a key step in terms of increasing intra-regional trade and cross-border exchanges within the regional context.

Examples include:

- investment of US\$24 million in a textile mill in Zambia along with further investment of US\$300 million into mines, manufacturing projects, construction companies and agriculture in Zambia ${ }^{75}$

- a plan to rehabilitate the Kamatanda copper and cobalt mines and three processing plants in Katanga province, Democratic Republic of Congo. This investment is worth around worth US\$27.5 million ${ }^{76}$

- implementation of an economic cooperation zone in Sierra Leone. Resulting in the establishment of around 20 Chinese companies, which produce a range of goods including spring mattresses, roofing tiles and hair lotions ${ }^{77}$

\footnotetext{
${ }^{75}$ Pg18, Ye Wang, Jian, 'What drives China's growing role in Africa', 2007, Working Paper, International Monetary Fund.

${ }^{76} \mathrm{Pg}$ 18, Ye Wang, Jian, 'What drives China's growing role in Africa', 2007, Working Paper, International Monetary Fund.

${ }^{77} \mathrm{Pg} 18$, Ye Wang, Jian, 'What drives China's growing role in Africa', 2007, Working Paper, International Monetary Fund.
} 
- a Chinese telecommunications company (Huawei) which facilitates the advancement of infrastructure by offering wireless technology CDMA products $^{78}$

- Chinese companies are working to improve telecommunications in other states, such as the work of the ZTE Corporation International in Angola. Here ZTE has built a fixed line telecommunications utility. ZTE invested around US\$400 million to build Angola's telecom network, upgrade the military telecommunications system, and construct a mobile phone factory

- in Nigeria, Chinese activity is supporting the progress of light industry. For example, Hashan company has invested US\$6 million in the local shoemaking industry. 79

Another key vehicle in terms of advancing intra-region trade within the African regions is the creation of new markets for African goods. If African industries can increase the ability to sell their goods in general, then this should hopefully allow these industries to become more productive and viable. If these industries are more viable in general, then it is more likely that they will be able to increase their possibilities for intra-regional trade. China can be seen to be supporting the long term goal of increasing intra-regional trade amongst Africa's region by facilitating the creation of more markets for African goods. China has begun this facilitation effort by expanding the list of duty free exports it accepts into its domestic market from Africa. China is also seeking to create trade cooperation zones within Africa to further aide these efforts. ${ }^{80}$.

\footnotetext{
${ }^{78}$ Pg18, Ye Wang, Jian, 'What drives China's growing role in Africa', 2007, Working Paper, International Monetary Fund.

${ }^{79} \mathrm{Pg} 18$, Ye Wang, Jian, 'What drives China's growing role in Africa', 2007, Working Paper, International Monetary Fund.

${ }^{80} \mathrm{Pg} 13$, Wang, Jian-Ye, 'What Drives China's Growing Role in Africa' . 2007, Working Paper, International Monetary Fund.
} 
One of the most pertinent statements form China's African Policy Paper relative to the facilitation of intra-region trade, was a commitment to launch free trade area negotiations with the Southern African Customs Union. ${ }^{81}$ This can be seen as the starting point from which China will negotiate free trade agreements with the other regionalisation organisations. Here China is directly supporting the progress of deeper integration between itself and the regional organisations, and in turn advancing the progress of new regionalism in general. It is likely that by encouraging agreements between itself and other regional groups it may be working to support the long term goals of these groups. This could conceivably happen via technical assistance to the African economic institutions, which would result through increased contact between Chinese officials with expertise in these areas.

As was referred to in previous sections and above, the sometimes crippling nature of state debt within Africa has seriously hamstrung efforts at regional integration. The Chinese development efforts with their African partner states have addressed this need. President Hu Jintao reaffirmed China's commitment to help African states get their debt levels and repayment structures under control at the 2006 Summit. He stated that China would double its assistance levels as at 2006 relative to grants and debt relief. China would also cancel all interest free loans owed by eligible countries that would mature at the end of $2005 .^{82}$

Increasing capacity in a variety of different sectors of African economies has been highlighted as an important part of the new regionalism projects on the continent. This is particularly relevant within the West African context. For example, ECOWAS has indicated that increasing the capability and technical proficiency is a key part of

\footnotetext{
${ }^{81} \mathrm{Pg} 17$, Ye Wang, Jian, 'What drives China's growing role in Africa', 2007, Working Paper, International Monetary Fund.

${ }^{82}$ Pg13, Wang, Jian-Ye, 'What Drives China's Growing Role in Africa' . 2007, Working Paper, International Monetary Fund.
} 
their long term strategies. While increasing the capabilities and diffusion of new technology within industry may not seem like an 'integration' agenda, it is part of the wider regionalisation project as signified by the ECOWAS example. China has signalled it wishes to support this facet of new regionalism via provided technical assistance where applicable. The Chinese government stated that they would provide training for African professionals via a programme whereby Chinese agricultural experts would be sent to Africa. Beijing has also stated they would support the establishment of agricultural technology demonstration centres in Africa. In a more general sense relative to increasing technological and academic capacity China stated that it would double the scholarships it will offer to African students. ${ }^{83}$

At this point it will be worth returning to the original question namely, has China directly supported the progress of new regionalism in Africa? Based on the above statements there appear to be many examples of how China has indeed supported the projects and initiatives fundamental to the advancement of new regionalism on the continent. China has supported the facilitation of investment on the continent; this has resulted in an influx of wan into many African states. Of particular interest to this article are the investments in local industry and infrastructure capacity building. Beijing has supported the development of African industries in a wider sense by opening up new markets for their products. The development of African industry should go some way to promote intra-region trade and thereby support the wider regionalism agenda. They are further supporting domestic African industry via provided expert technical advice and training. Although the above examples do not refer to China's supporting new regionalism in a direct financial sense, I believe they show Beijing has committed itself to support a wider range of 'development' and

\footnotetext{
${ }^{83}$ Pg13, Wang, Jian-Ye, 'What Drives China's Growing Role in Africa' . 2007, Working Paper, International Monetary Fund.
} 
'capacity' style initiatives which will allow the regionalisation organisations to become more capable and therefore more likely to meet their long term goals.

\section{Conclusion}

The original intention of this article was to attempt an empirical investigation into the impact of China on new regionalism in Africa. This has proved to be a fairly complicated process, not only due to the somewhat abstract and confused means and ends of the integration organisation, but also due to the fact that China does not have an 'official policy on African regionalisation' as such. With this in mind I sought to undertake a very focused approach to this task, via focusing on specific regionalisation organisations and also on a specific 'empirical investigation scheme'. Namely, by restricting the investigation to the organisations that do have a relationship with the Chinese government, I believe I have offered up a practical outline of new regionalism in Africa from which we can investigate the impact of China on this paradigm of integration. As 'new regionalism' represents a new approach to the old goal of regional integration, it seemed that it may be particularly relevant to review the impact of THE 'new global power' on this form of regionalism.

Before any investigation into China's impact on regionalisation was attempted, an explanation and discussion on a specific regionalism paradigm was offered. The focus on the agreements, organisations and projects characterised as 'new regionalism' was chosen due to the recent prevalence of these sorts of fresh approaches to integration within the globalised trade environment. Given Africa's geography, prevalence of resources (both human and material) and currently underdeveloped infrastructure, this continent could potentially benefit greatly from regional economic integration as represented by the 'new regionalism' paradigm. The what, why and how of new regionalism was explained through a comparison with 
previous attempts at regional integration characterised via the 'old regionalism' paradigm. The concept of new regionalism was further elucidated by outlining its practical manifestations in groups such as the African Union, Southern African Development Community and The Economic Community of West Africa States. These groups were given coverage by referring to their goals, strategies and visions for what regional integration can do for Africa. This section was to provide the conceptual background regarding what new regionalism is and how it applies to the African context.

Once the conceptual and practical framework was laid down in terms of what new regionalism is, the next task was to review the nature and scope of China's activities in Africa relative to this. This section covered China's idealised dealings with Africa via its African policy document. The idealised nature of 'China's Africa Policy' was given empirical grounding via reference to levels of Chinese investment, the nature of Chinese backed infrastructure projects and the Chinese governments' actions relative to trade policy with African states. The intention of this section was to provide a true empirical background in terms of China's actions relative to the new regionalism in Africa. By outlining this background it was hoped that a more solid position would be gained from which an attempt to review China's impact on new regionalism could be launched.

The final section was an attempt to bring everything together, namely compare Chinese actions relative to practical manifestations of new regionalism to see whether China has had a positive or negative impact on the progress of this form of regional integration. The first of the two 'empirical vehicles' for this investigation was to compare previous stumbling blocs which have plagued new regionalism against China's actions relative to these issues. These stumbling blocks included things like lack of progress in infrastructure development, the use of closed markets as a vehicle 
for economic development and the constricting nature of debt repayment conditionalities. It was found that China had been supporting efforts to overcome these issues through initiatives such financing infrastructure development, opening up Chinese markets to African goods and offering very favourable debt forgiveness arrangements. The second 'empirical vehicle' was an outline of direct Chinese support for the new regionalism agenda in Africa. This included further detail on the Chinese government's commitments to infrastructure development, peace keeping operations, debt cancellation and trade policy. All of these initiatives can be seen to be directly support the new regionalism agenda as espoused by groups such as the African Union.

A complete objective assessment of how China has impacted the advancement of new regionalism in Africa is a very complicated and lengthy process, a task which for the purposes of this style of article must be constrained in certain senses. However, by focusing on specific groups and on a tightly focused empirical review method, I believe an interesting and relevant investigation has been offered. It is the contention of this article, based on the groups reviewed and schemes employed, that China's actions have supported and promoted the cause of new regionalism in Africa. The commitments espoused by the Chinese government's African Policy, and the empirical data which backs up these statements, speaks to a real partnership between China and the African regional integration organisations. However, only time will tell whether this partnership will produce the long term goals highlighted in the strategic documentation of groups such as the African Union. Furthermore, even if these organisations do meet the goals they have set themselves, the jury is out on whether these goals will deliver real benefit in terms of any increases in the quality of life for Africa's people.

\section{References}


Mistry, P.S., 2000. 'Africa's record of regional co-operation and integration', African Affairs, 99: pp 553-573.

The Economic Community of West African States, Sahel and West Africa Club (SWAC) \& Organisation for Economic Co-operation and Development (OECD), 2006. 'Atlas on Regional Integration in West Africa', Paris, France, SWAC/OECD.

Commission of the African Union, 2004. 'Strategic Plan of the Commission of the African Union, Volume 2: 2004-2007 Strategic Framework of the Commission of the African Union', Addis Ababa, Ethiopia, Commission of the African Union.

Commission of the African Union. 2004. 'Strategic Plan of the Commission of the African Union, Volume 3: 2004-2007 Plan of Action, Programmes to speed up integration of the continent', Addis Ababa, Ethiopia, Commission of the African Union.

African Union Commission - Directorate for Strategic Planning, Policy, Monitoring, Evaluation and Resource Mobilization (2009). 'Strategic Plan 2009-2012', Addis Ababa, Ethiopia, Commission of the African Union.

Broadman, H.G., 2008. China and India Go To Africa - New Deals in the Developing World. Foreign Affairs, [internet] March/April 2008. Available at: http://www.foreignaffairs.com/articles/63224/harry-g-broadman/china-and-india-go-toafrica [Accessed 9 November 2009].

Goldstein, A. Pinaud, N. Resin, H. \& Chen, M.X., 2006. The Asian drivers and Africa - learning from case studies. [Online] Paris, France: Organisation for Economic Co- 
operation and Development (OECD) Development Centre (Published December 2007) [Accessed November 20 2009].

Alden, C. 2005. China in Africa, Survival, 47:3, pp 147-164, Autumn, 2005.

Chinese Government, China's African Policy, 2006. Beijing, China, Chinese Government.

Thompson, D., 2005. China's Soft Power in Africa: From the 'Beijing Consensus' to Health Diplomacy. China Brief, 5 (21).

Rosen, D.H. \& Hanemann,T., 2009. China's Changing outbound Foreign Investment Profile: Drivers and Policy Implications, Peterson Institute for International Economics, Washington, United States, June, 2009.

Gibb, R.A., 1987. The Effect on the Counties of the SADCC of Economic Sanctions against the Republic of South Africa. Transactions of the Institute of British Geographers, 12 (4) pp 398-412.

Hettne, B. Soderbaum, F. \& Stalgren, P, 2008. The EU as Global Actor in the South., Report No 8, Swedish Institute for European Policy Studies, Stockholm, Sweden, June, 2008.

Jiaboa, Premier Wen. 2009. 'Speech at $4^{\text {th }}$ Ministerial Conference on Forum on China-Africa Cooperation', The Fourth Ministerial Conference of the China-Africa Cooperation Forum, Sharm el-Sheikh, Egypt, November 8, 2009. [Online] Available at http://news.xinhuanet.com/english/2009-11/09/content 12413102.htm [Accessed 12 December 2009]. 
Taylor, I., 2003. Globalization and Regionalization in Africa: Reactions to attempts at Neo-Liberal Regionalism. Review of International Political Economy, 10 (2): pp 310330, May, 2003.

Soderbaum, F., 2004. Modes of Regional Governance in Africa: Neoliberalism, Sovereignty-boosting and Shadow Networks. Global Governance: A Review of Multilateralism and International Organizations, 10 (4): 419-436, November, 2004.

New Partnerships for Africa's Development (NEPAD). 2001. 'NEPAD Programme of Action', Abuja, Nigeria, (NEPAD).

International Monetary Fund, 2007. 'World Economic and Financial Surveys, Regional Economic Outlook - Sub-Saharan Africa', Washington D.C, United States, International Monetary Fund.

Soderbaum, F, 2007. Regionalisation and Civil Society: The Case of Southern Africa. New Political Economy, 12 (3), September, 2007.

Burfisher, M.E. Robinson, S. \& Thierfelder, K. 2003. Regionalism: Old and New, Theory and Practice. In: The International Agricultural Trade Research Consortium (IARTC). Agricultural policy and reform and the WTO: where are we heading? Capri, Italy, June 23-26, 2003.

Mittlelman, J.H, 1996. Rethinking the 'New Regionalism' in the Context of Globalisation. Global Governance, 2 (1996), pp 189-213. 
Ramo, J.C., 2004. The Beijing Consensus. [Online] London, UK: The Foreign Policy Center (Published 2004) Available at http://fpc.org.uk/publications/TheBeijingConsensus [Accessed 30 December 2009].

Zafar, A., 2007. The Growing Relationship between China and Sub-Saharan Africa: Macroeconomic, Trade, Investment and Aid Links. The World Bank Research Observer [Online] 22 (1), Available at http://wbro.oxfordjournals.org/cgi/content/abstract/lkm001v1 [Accessed November 19 2009].

Goldstein, A. 2002. The New Regionalism in Sub-Saharan Africa: More than meets the eye? OECD Development Centre Policy Briefs [Online] 20, Available at http://ideas.repec.org/p/oec/devaab/20-en.html [Accessed January 18 2010].

Ethier, W.J., 1998. The New Regionalism. The Economic Journal [Online] 108 (449) pp 1149-1161, Available at http://www.jstor.org/stable/2565673 [Accessed January 12 2009].

Wang, J.Y. 2007. What Drives China's Growing Role in Africa? IMF Working Papers [Online] 07/211, Available at http://ideas.repec.org/p/imf/imfwpa/07-211.html [Accessed December 31 2009]. 